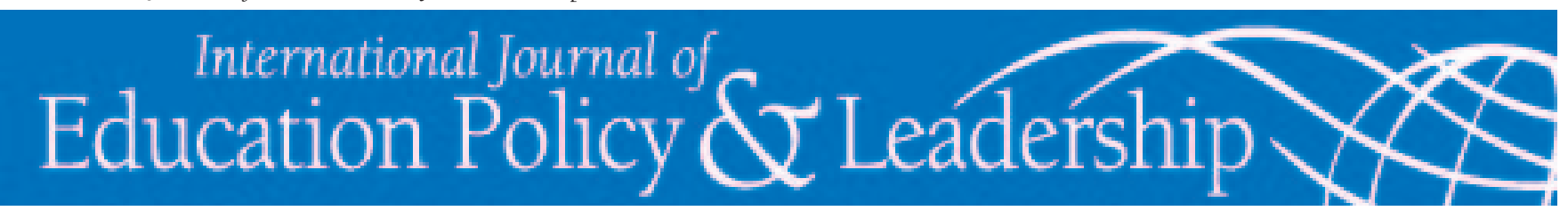

\title{
THE KINDS OF KNOWLEDGE PRINCIPALS USE: IMPLICATIONS FOR TRAINING
}

\author{
ANGELIKI LAZARIDOU \\ University of Thessaly
}

\begin{abstract}
Information about how school principals operate pertains mainly to the actions of principals. However, the kinds of knowledge that the principalship demands have not been isolated as clearly, more often than not being conflated with actions. As principals' duties become more complex, it becomes more important to ground specific practices in robust knowledge of relevant theoretical principles. One aspect of the principal's job where this is particularly germane is the resolution of unfamiliar, complex, unstructured challenges. This paper presents findings from research into how principals think when dealing with problematic situations, in particular the types of knowledge they use. Four broad categories of knowledge were identified and, within those, twelve specific types. The research lends credence to the oralreport or think-aloud method for making thinking processes available for analysis, and the findings indicate how the content of preparation programs may be adjusted to better qualify principals for the contemporary demands of their work. A prime recommendation is the inclusion of opportunities for the development of tacit knowledge.
\end{abstract}

Lazaridou, A. (2009). The Kinds of Knowledge Principals Use: Implications for Training. International Journal of Education Policy and Leadership 4(10). Retrieved [DATE] from http://www.ijepl.org.

\section{Introduction}

As many now point out (e.g., Anfara and Valentine, 2004), there is no disputing that school principals contribute much to the successes of their schools; instead, attention has now returned to the challenges of mapping "the pathways by which leaders exercise their influence in schools" (Southworth, 2004, p. 97). An important question in this regard concerns the kinds of knowledge that principals need and how they use that knowledge. In this paper I report research that addresses these issues.

\section{Justifications for the Study}

The need to refine understandings of the tools principals use when they work to influence events in and around their schools has acquired greater urgency because of three interacting factors:

1. In many jurisdictions there is a crisis in succession.

2. In many instances preparation programs appear to be deficient, even misdirected.

3. There is uncertainty about the kinds of knowledge principals now need.

\section{The succession issue}

Many education jurisdictions are experiencing a principal succession crisis, something that has long been anticipated. Table 1 provides just a few examples of the international documentation (see Table 1, page 2). Clearly, leader preparation is a critical issue in many locations.

To compound the problem, a worrisome aversion to the office of principal has become evident. For example, in a recent survey of educators in the UK, Munby (2006) found that 30-40 percent of deputy heads and middle leaders did not aspire to the principalship for a variety of reasons: the onerous demands and stress of the job, personal commitments, reduced contact with students, reduced teaching, just not a personal ambition, and accountability pressures. Similarly, in the United States, the National Association of Secondary School Principals (Quinn, 2006, p. 1) reported the disincentives of the principalship as increased job stress, inadequate school funding, balancing school management with instructional leadership, new curriculum standards, educating an increasingly diverse student population, shouldering responsibility that once belonged at home or in the com- 


\begin{tabular}{|l|l|}
\hline Table 1: Too Few Principals \\
\hline Canada & $\begin{array}{l}\text { In 2000, Jones predicted that between } 1995 \text { and } 2005 \text { the } \\
\text { Calgary Board of Education, one of the largest Canadian } \\
\text { urban school districts, would have to replace more than } 85 \% \\
\text { of its incumbent principals. }\end{array}$ \\
\hline USA & $\begin{array}{l}\text { Bottoms and O'Neill (2001) predicted that by 2005, 40\% } \\
\text { principals and 50\% of superintendents in the United States } \\
\text { would reach retirement age. }\end{array}$ \\
\hline $\begin{array}{l}\text { Australia and New } \\
\text { Zealand }\end{array}$ & $\begin{array}{l}\text { In 2002 the Australian Principals' Association Professional } \\
\text { Development Council reported that it was concerned about a } \\
\text { looming principal shortage and was investigating. } \\
\text { In NZ, Brooking (2007) and Hodgen and Wylie (2005) have } \\
\text { documented high turnover rates for school principals. }\end{array}$ \\
\hline Greece and Cyprus & $\begin{array}{l}\text { Time spent in the principalship tends to be very short } \\
\text { because individuals often are not eligible for the post until } \\
\text { they are in their 50s (Athanasoula-Reppa, Lazaridou, and } \\
\text { Lyman, 2006); consequently, turnover rates are high. }\end{array}$ \\
\hline UK & $\begin{array}{l}\text { The National College for School Leadership (2006) has } \\
\text { underway a national program to develop ways of alleviating } \\
\text { a shortage of heads and deputy heads. }\end{array}$ \\
\hline
\end{tabular}

hand and pressures from colleagues (as well as numerous stakeholder groups in the school's community) for leadership that is more participative, open, and unguarded than the traditional patriarchal or "heroic" form (e.g., Lyman, Ashby, and Tripses, 2005; Lyman, AthanasoulaReppa, and Lazaridou, 2007; Lazaridou and Fris, 2008).

In short, today's principals need to be equipped with highly specialized skills and knowledge, many of those skills having to do with negotiating interpersonal and political dynamics. Yet there seems to be little training that focuses specifically on the newer demands of the role and for school improvement efforts (Elmore, 2000; Farcas, Johnson, Duffett, Foleno,

munity, and facing possible termination if their schools did not show instant results. And Normore (2004) refers to surveys that show fewer teachers coveting the principalship as an opportunity to improve their salaries, prestige, or respect among other colleagues, and that "the complexities, changing demands, and expectations within administrative roles have caused a shortage in applicant pools."

In general, then, the succession issue involves not only a shortage of candidates for the principalship but a shortage of experienced mentors for those candidates. Valuable experiential and tacit knowledge is disappearing.

\section{The preparation programs issue}

There is wide agreement that all too often training programs have been and continue to be unimaginative, overly theoretical, impervious to reform, and lacking the wisdom that is inherent in the tacit knowledge of practitioners (Archer , 2005; Creighton and Jones, 2001; Daresh, 2002, Doud and Keller, 1998; Fenwick, 2000; Ferrandino, 2001; Lashway, 2003).

To some extent the problem is a product of the discourse on the principals' role having long promoted the image of one strong leader. Consequently, many training efforts aimed to strengthen the principal's authority as manager and instructional leader - and to develop the commensurate skills. However, in many instances decentralization of school governance has come into favour, with the result that school principals now need skills for negotiating the tensions between the bureaucratic press for efficiency and authoritative leadership on the one and Foley, 2001; Ferrandino, 2001; Farkas, Johnson, and Duffett, 2003; Levine, 2005; Hess and Kelly, 2006).

\section{The knowledge issue}

In the literature about training for principals, much attention is given to listing the principal's responsibilities and to identifying the skills needed to fulfill those duties (e.g., Bottoms and O'Neill, 2001; Thomson and Legler, 2003; Association of Washington School Principals, 2006). The accumulated information can be confusing because there is much duplication and because the terms "skill" and "knowledge" are not differentiated clearly, but rather are often are used interchangeably.

Much of the information about school principals' responsibilities pertains to the "what to do" and "how to do it" of the principalship. For example, in a recent study Hess and Kelly (2006) characterized the seven primary dimensions of effective school leadership as managing educational results/achievements, personnel, technology, external relationships, norms and values, classroom instruction, and school culture. Further, the findings from recent large-scale international studies have been very helpful in identifying the activities and strategies that effective school leaders foster to deal with the complexities and problems of the contemporary principalship (e.g., Day, 2005; Fullan, 2001; Leithwood and Jantzi, 2006; Leithwood, Mascall, Strauss, Sacks, Memon, and Yashinka, 2007; Valentine, Clark, Hackman, and Petzko, 2002). However, the kinds of knowledge that the school principalship demands have not been isolated as clearly, more often than not being conflated with actions. 
The word "skill" is defined variously as follows: - A skill is an ability, usually learned and acquired through training, to perform actions which achieve a desired outcome (Wikipedia, 2009).

- An elementary action requiring manual or verbal dexterity that is necessary for performing a compound or complex set of actions in order to accomplish a particular task; the ability to do something well arising from training or practice; "know-how" (Eshleman, 2008).

In such definitions, skills are primarily behavioral. Some definitions, though, recognize skill in cognition:

- Skill refers to a person's ability to perform various types of cognitive or behavioural activity effectively (Prentice Hall, 2008).

Some definitions distinguish "skill" and "knowledge" implicitly, as in the following:

- Skill is the physical capacity for effective performance. Skill can only be determined by physical demonstration. For a child to know the letters of the alphabet in their proper order is an example of knowledge; to be able to speak them out loud in an intelligible fashion is an example of a skill (KM-Experts, 2008).

- Academic knowledge is the conceptual foundations of a very complex field; it provides a common language to talk about the problems of practice; but it provides only part of what principals need to know. Practical experience is of pragmatic value; but it is grounded in existing practices, which militates against reform (Daresh, 2002).

Sometimes the distinction is made explicit, for example in the exhortation by Bottoms and O'Neill (2001, pp. 9-17) that school leaders be inculcated with knowledge in a dozen or so areas, including knowledge of research supporting changes in curriculum, instruction, school practices, and organizational structures; knowledge of national, state, and local achievement standards; knowledge of principles for getting parents, teachers, and community members to subscribe to the school's mission; and knowledge of how computers and the Internet can be used to enhance students', teachers', and their own learning.

When the distinction between skills and knowledge is maintained, a review of the literature indicates that administrators use three or four kinds of knowledge. For example, Mumford, Zaccaro, Harding, Jacobs, and Fleischman (2000) isolated three types of knowledge: of people, of the tasks at hand, and of the organization. Similarly Sternberg (1985) and Wagner and Sternberg (1985) found that the following kinds of knowledge were important for managerial success:

- Managing people - knowing how to work with and direct the work of others.

- Managing tasks - knowing how to manage and prioritize day-to-day tasks.

- Managing self - knowing how to maximize personal performance and productivity.

- Managing career- knowing how to build one's reputation.

Further, it has been suggested that when principals deal with unfamiliar, complex, unstructured challenges, tacit knowledge is critical. Tacit knowledge is a second-order type of knowledge that regulates how context-specific knowledge and skills should be adapted and applied. It is the product of metacognition. This is a kind of knowledge that distinguishes experts (Author, 2002; Wagner and Sternberg, 1985 and 1986):

- An expert within a specific domain has a large and well-organized, context-specific knowledge base.

- Further, experts have tacit knowledge, which allows them to identify patterns and configurations quickly, and to classify tasks and challenges according to principles, laws, or rules, rather than surface features.

- Acquisition of tacit knowledge takes a long time; it requires years of practice, experience, and study.

The nature and role of tacit knowledge, however, have been explored systematically in military and commercial settings (e.g., Wagner and Sternberg, 1985; Mumford et al, 2000) but only to a limited degree in educational administration (e.g., Allison and Allison, 1993; Leithwood and Steinbach, 1995; Nestor-Baker and Hoy, 2001).

In the remainder of this paper I present findings from my research into how principals think while dealing with challenging situations- in particular, my findings about the types of knowledge they use.

\section{The study}

\section{Context}

The findings reported here came from a study of how principals think through typical administrative challenges. It was prompted by research in both non-educational and educational organizations (e.g., Ericsson and 
Charness, 1994; Leithwood and Jantzi, 1989, 2006) which has shown that leaders' thinking processes and strategies are important determinants of their effectiveness. The research also suggests that the kinds of knowledge leaders use is another significant factor (Mumford, Zaccaro, Harding, Jacobs, and Fleishman, 2000). But there is relatively little literature of this type for educational organizations. Accordingly, one of the questions I addressed with my study was, "What kinds of knowledge do principals use as they come to grips with challenging situations?"

\section{Participants}

I asked senior administrators in two school districts, one urban and one suburban, in a Western Canada province to provide the names of "effective" principals in their employ who might agree to participate in the study. They

\begin{tabular}{|c|l|}
\hline \multicolumn{2}{|c|}{ Table 3- Nature of the Cases } \\
\hline Human relations & $\begin{array}{l}\text { A conflict between a classroom teacher and a teaching assistant in a } \\
\text { class with special-needs students during a social science exam. }\end{array}$ \\
\hline 2 & $\begin{array}{l}\text { System downsizing and the transfer of a teacher into a classroom } \\
\text { with high-need students. }\end{array}$ \\
\hline 3 & Disciplining a student who used abusive language toward a teacher. \\
\hline Strategic & $\begin{array}{l}\text { Changing a school's philosophy from a traditional mode to a more } \\
\text { inclusive one. }\end{array}$ \\
\hline 4 & $\begin{array}{l}\text { The impact of financial constraints and low enrollment along with a } \\
\text { restructuring policy on staff empowerment. }\end{array}$ \\
\hline 5 &
\end{tabular}

\section{Data collection procedures}

Data were gathered with five short case descriptions that featured ill-structured problems insofar as the initial or goal states were not clearly stated, the principal had to make some assumptions, and there was more than one possible solution (Taylor and Dionne, 2000).

The cases contained one or more administrative issues that the participants were asked to identify and provided 20 names and I

derived a purposive sample from this list, striving to ensure that the sample reflected a mix of age, experience, and gender. Three of the principals came from the suburban school board; the other seven were from the urban board. Table 2 summarizes the demographics of the sample.

\begin{tabular}{|l|c|c|c|c}
\hline Table 2: Participants' Demographics & \multicolumn{2}{l}{ Sumber } \\
\hline Principal & Gender & Experience & School & $\begin{array}{c}\text { of } \\
\text { students }\end{array}$ \\
\hline James * & M & 5 years & Elementary & $>300$ \\
\hline Karen & F & 2 years & Junior high & $>300$ \\
\hline Sharon & F & 2 years & Elementary & $>300$ \\
\hline Gerry & M & 14 years & Junior high & $>300$ \\
\hline Wendy & F & 14 years & Elementary & $>300$ \\
\hline Marina & F & 3.5 years & Elementary & $<300$ \\
\hline Keith & M & 2.5 years & Senior high & $<300$ \\
\hline Norm & M & 6 years & Elementary & $<300$ \\
\hline Christine & F & 2.5 years & Elementary & $<300$ \\
\hline Paul & M & 21 years & Elementary & $>300$ \\
\hline * Pseudonym & & & & \\
\hline
\end{tabular}

then resolve. The cases were based on true incidents drawn directly from the lives of real school principals. They were deemed to be typical of the challenges encountered by principals and they were of two types: strategic and human relations (See Table 3).

This study involved analyses of principals' oral accounts of what was going through their minds as they thought about how to solve the problematic situations that I presented to them in written scenarios. The oralreport method, or think-aloud process, is a well-established, reliable, and valid means for making thinking processes available for analysis (Kail and Bisanz, 1982; Pressley and Afflerbach, 1995). As recommended by Ericsson and Simon (1993), all participants were prepared for the think-aloud activity in a brief training session designed to familiarize them with the procedure. For this, participants were given a short written description of an administrative challenge (the training scenario) and were asked to think aloud while analyzing it and formulating a plan for dealing with it. After this training session, participants were handed the "real" scenarios, asked to read each one aloud and then to think aloud about how they would respond to it. Participants were encouraged to express all their thoughts from the moment that they were handed the scenarios until they had finished dealing with them. The think-aloud ses- 
sions lasted between 60 and 90 minutes. With the consent of the participants all sessions were audio-taped. Subsequently the recordings were transcribed and then verified for accuracy and completeness by the participants.

\section{Data analysis}

The transcripts/protocols were scanned for sentences and parts of sentences that evidenced the knowledge that was being used by the participants as they worked on the scenarios. This analysis and coding was done with the assistance of Atlas.ti, a computer program for qualitative analysis of unstructured data.

The data were scanned, first of all, for evidence of the three broad categories of knowledge in the typology of experts' knowledge that was developed by Mumford and colleagues (2000): knowledge of people, knowledge of the organization, and knowledge of the task. However, I also screened the transcripts for segments that seemed to evidence new types of knowledge. Whenever new categories emerged, they were integrated into or added to the initial framework. This was done to realize the advantages of building on an a priori typology:

(a) The results of an investigation are strengthened not only by applying a priori categories, but also by elaborating and refining those categories as more categories emerge across the data.

(b) Initial conceptualizations of the cognitive phenomena being studied can be enriched by integrating new patterns in the data that have been identified (Pressley and Afflerbach, 1995).

\section{Quality assurance}

Quality of the data and the findings was ensured by:

- Wording the standard instructions carefully, establishing good rapport, providing a "warm-up" session, allowing participants to work at a comfortable pace, and not interrupting them except to remind them to think aloud whenever they were silent for more than 10 seconds (Ericsson and Simon, 1993; Pressley and Afflerbach, 1995; Taylor and Dionne, 2000; Van Someren et al, 1994).

- Using novel but realistic scenarios (drawn from principals' actual experi- ences) that had been piloted with three principals who otherwise did not participate in the study (Bainbridge, 1990; Pressley and Afflerbach, 1995; Van Someren et al, 1994).

- Transcribing the oral reports verbatim, capturing as many verbal nuances as possible by including pauses, emphases, and indications of tone (Ericsson and Simon, 1993; Pressley and Afflerbach, 1995; Van Someren et al., 1994).

- Testing the reliability of data coding with intercoder checks by two other coders. Intercoder agreement was 0.9 and 0.96 .

\section{Findings}

Based on the findings from previous research, three general categories of knowledge were expected in the data: knowledge of the organization, knowledge of people, and knowledge of tasks. The analysis of the principals' protocols confirmed the presence of these general types

\begin{tabular}{|c|c|c|}
\hline \multicolumn{3}{|l|}{ Table 4 - Types of Knowledge } \\
\hline Type of knowledge & $\begin{array}{c}\text { \# of segments } \\
\text { in the } \\
\text { transcripts }\end{array}$ & $\%$ \\
\hline \multicolumn{3}{|l|}{ Knowledge of the organization } \\
\hline External constraints & 16 & 7 \\
\hline Internal constraints & 21 & 9 \\
\hline Job complexity & 8 & 3 \\
\hline Laws and regulations & 27 & 11 \\
\hline Resources & 13 & 5 \\
\hline Time & 11 & 5 \\
\hline Subtotal & 96 & 40 \\
\hline \multicolumn{3}{|l|}{ Knowledge of people } \\
\hline Completing interests & 15 & 6 \\
\hline Knowledge of self & 15 & 6 \\
\hline Strengths and weaknesses & 6 & 3 \\
\hline Working with people & 57 & 24 \\
\hline Subtotal & 93 & 39 \\
\hline \multicolumn{3}{|l|}{ Knowledge of tasks } \\
\hline Roles and responsibilities & 22 & 9 \\
\hline \multicolumn{3}{|l|}{ Tacit knowledge } \\
\hline Schemata & 29 & 12 \\
\hline Total & 240 & 100 \\
\hline
\end{tabular}


of knowledge and revealed one new category. Table 4 shows the four general categories of knowledge and the twelve specific sub-types of knowledge, together with their distributions.

Before I describe these kinds of knowledge, two cautions are in order. First, the separation of the primary types and subtypes was a complex process, and the final "solution" is, as with any analysis for threads in verbal data, open to questions of semantics. However, as noted above, the typology was verified by independent coders. Second, the neat separation of categories of knowledge obscures overlaps and complex relationships among the types. In addition, the typology hides the fact that the principals often used various knowledge types simultaneously. For example, when working with people, it helped if the principal was able to capitalize on strengths and minimize weaknesses while dealing with competing interests.

\section{Knowledge of the organization}

This class of knowledge was referenced most frequently by the principals. It included six distinct subtypes, as follows.

\section{Knowledge of external constraints}

This subcategory comprised statements that indicated awareness of external constraints that restricted the range of possible decisions and actions. The constraints related to such external factors as community, union, school board, and other policies that limited a principal's role in decisions that affect the school. The following excerpts are illustrative:

I don't think you can impose a philosophy amongst staff, students, and parents without feedback from them. This isn't the principal's school, it's a community school. (Marina, problem 2)

I think ultimately you need to do what's best for your school and what's best for your class. [But] we don't always have full control over who we get in our school, and who teaches what. ... If you could hire whoever you wanted, life would be great. But you can't do that because of unions, hiring factors, and all of those kinds of things. (Christine, problem 4)

\section{Knowledge of internal constraints}

The principals also identified other factors within the organization that they knew restricted potential solutions to the problems depicted in the cases. Examples of such are in the following quotations:
If you want to be liked by everyone, you won't survive in the principalship. I mean, every parent isn't going to like you. Every kid isn't going to like you. Every teacher isn't going to like you. That's just one of the realities of the job. (Wendy, problem 5)

One of the [facts] I live with is that not everyone's going to agree with the final decision. But when we walk out of a meeting, we all must live with the decision. (Paul, problem 3)

As an administrator, you have to be able to put out some parameters as far as the decision-making is concerned. It can't be wide open to the point where you say, "Well, we're going to get rid of the secretary. We don't need a school secretary." There are certain things that are touchables and certain things that are untouchables. (Norm, problem 3)

\section{Knowledge of the complexity of the job}

Another type of knowledge that was referenced as the principals thought aloud was acknowledgement of the complexity of the principals' job. For example:

That really changes the role of the principal. More and more, we're doing things that aren't related to instructional leadership. I mean, we're an educational institution, and I deal with teaching and learning as my primary responsibility. But now we're faced with so many other things that there has been a bit of a shift, and I struggle on a daily basis in terms of trying to make sure that the balance isn't lost. I manage all the resources, yet I have to make sure that the school moves forward educationally. And it's complex, ... the role of the principal. (Wendy, problem 2)

\section{Knowledge of the laws and regulations}

At times the principals referred explicitly to the rules and regulations that govern a school. Statements put in this category related to such issues as teachers' roles and responsibilities, school board policies, and professional codes of behavior, among others. The following quotations illustrate this subcategory:

The teacher is responsible for what goes on in the classroom, for designing lessons, and for making sure that the program is implemented and evaluated with the student. A teaching assistant's role is to assist the teacher, so in a sense the teaching assistant really has to do what it is the teacher expects, and they work collaboratively. (Wendy, problem 1) 
Generally, principals decide themselves who teaches. The superintendent would decide how many teachers you would get, and what programs you run, but generally in our tradition, the principal actually makes the decision who teaches the class. (Keith, problem 4)

\section{Knowledge of resources}

Another type of knowledge the principals referred to concerned the resources that were accessible through the school system and the resources that the principals could provide for their schools:

I would give her every opportunity for assistance, consultative assistance, assistance from the system as much as I could, assistance from myself, and any other support staff. (Sharon, problem 4)

There are a number of sponsors that could probably provide us with some support, but then again, proposal writing takes a lot of time. But we've got a number of options: looking at the Boys and Girls Club as support, mentorship programs, etc. (Marina, problem 3)

Maybe distribute articles at staff meetings to read about inclusive education. Go on some visits to schools that do a lot of inclusive education; let them see what it looks like; let them talk to other teachers. And then start asking what their concerns are, and start addressing those through inservices and consultants. (Christine, problem 2)

\section{Knowledge of time}

Principals' awareness of the timing of events constitutes another subcategory of organizational knowledge.

And, as I said, that is not something you're going to do in a month, or a year, I'm looking at a fiveyear timeline. (Sharon, problem 2)

If they say that by next September we're going to have this model, then we're going to have a series of workshops [through] December, January, February, March, and April to plan it. And even if it [turned out to be] a terrible model, at least we know what we're doing. (Keith, problem 2)

\section{Knowledge of people}

Four subcategories of knowledge that emerged from the data were classified under this heading: knowledge of competing interests, of self, of people's strengths and weaknesses, and of working with people.

\section{Knowledge of competing interests}

This subcategory encompasses knowledge about dealing with conflict and individuals with different interests. Some examples are in the following excerpts:

I very much believe in embracing negativity, going to negativity, going to the negative ones and saying, "I really want to understand more about where you're coming from." (Sharon, problem 2)

You don't get everybody all the time, but I don't spend a lot of time with the people who are not helping; I spend more of my time and energy and attention with the people who are helping us. (Norm, problem 4)

\section{Knowledge of self}

Statements that were indicative of the principals' awareness about themselves and their personal philosophies, belief systems, and values constitute this subcategory. The following excerpts are illustrative:

And sometimes even in situations that are sticky and very uncomfortable and distasteful, you still have to be honest. (Gerry, problem 4)

If a teacher comes to me and says they're going to be resigning, and the reason for their resignation is the unclear and disorganized [climate], I think that's really food for thought rather than to dismiss it altogether. One of the things that reflection helps me do is to look at whether I have really considered everything that one could possibly consider that might impact a particular situation. I sometimes find, when I reflect, that I've not been a good listener, or I've spoken too much, or I've been too hasty in coming to resolution of a problem. It helps me grow when I reflect. (Wendy, problem 2)

\section{Knowledge of people's strengths and weaknesses}

Statements that revealed awareness of the strengths that individuals bring to a specific situation constitute this subcategory. Included here were principals' acknowledgements of their own weaknesses and mistakes.

We have a very valuable educational assistant in her. She has a lot of good skills. How could we best put her skills to use? (Sharon, problem 1) I would have to come and talk to the staff and say, "Look, I think I've made an error here." (Paul, problem 2)

So if that was the case, I think that I would have to tell the staff that I messed up, and take the blame for that. (Christine, problem 2) 


\section{Knowledge of working with people}

Statements I put in this subcategory are ones that indicated awareness of how to relate to other people, such as teachers, students, and parents.

Helping kids develop some discipline, helping them develop some values and a set of beliefs that will serve them long term, so that when they are engaged in behaviors that are inappropriate for living together in a community, we have to help them understand what that does to not only their position within our learning community, but also in the larger community. (Wendy, problem 5)

I think that any kind of positive that you can give to the staff, whether verbally, by e mail, a little recognition, a treat in the mailbox, goes a long way. (Marina, problem 1)

I believe that the very first thing, that there should be some type of trust relationship built up with the staff. I think it shouldn't be top down. (Paul, problem 2)

\section{Knowledge of tasks}

Statements assigned to this category were descriptive of the specific roles and responsibilities principals assumed in their jobs. Statements of this sort are exemplified in quotations such as these:

I always work from a point of saying to teachers, "My role is to make you successful. Now, you have the role of letting me know what will make you successful so I can support you. So, it's more a partnership." (Wendy, problem 4)

My job would be to look after the whole school and the staff, and assign them to where they're best qualified and best able to teach. There are only so many things a school can do, and I would be responsible for those things that are part of our responsibility, but also pointing out the things that are not part of our responsibilities. (Keith, problem 3)

\section{Tacit knowledge}

Another category of knowledge that was evident in my data is the one that has been identified rather tentatively in the literature: tacit knowledge. This category captures principals' references to abstract, general insights, gained from a number of similar past experiences, which they used to support and/or justify a particular approach to a scenario. As mentioned previously, this kind of knowledge comprises second-order understandings or schema- ta (Leithwood and Steinbach, 1995, p. 126) that allow administrators to recognize previously encountered macro-patterns and configurations and to respond to them according to principles or "rules of thumb" rather than micro-level features. For example, statements put in this category include the following, which have been synthesized from non-contiguous segments of the protocols and in which I have underlined the segments that intimate the use of tacit knowledge:

I have had previous personal experience with this, so I made it very clear to [central office] personnel that I may need assistance with this placement and ... what they could do. So I had a plan and commitment before I even met the teacher, and I made it very clear to the teacher what the situation was. It was very supportive. We gave her all kinds of supports. We put everything into place. (Sharon, problem 4)*

I've previously had people here who were identified as "being in difficulty." So, my first meeting with the staff member was to say ... to be honest, to say to them, "You have been identified as someone who's experiencing some difficulty, but let's start here by saying we're going to get rid of whatever that difficulty is, and we're going to work together so that you're successful." (Wendy, problem 1) *

It worked effectively in the past, so hopefully that would work. (Marina, problem 2) *

* Synthesised from non-contiguous segments of the data protocols.

In the examples above, Sharon, Wendy, and Marina used schemata derived from past experiences as grounds for their solutions for the problems; in the next example Paul alludes to tacit knowledge that he used on an ongoing basis:

However, one of the things that we do as a matter of course at the school is that we put our best teachers in the most difficult situations. The tougher the assignment, that's where you move your best people. So I would probably not put this person with the toughest class and the toughest assignment. (Problem 4)

\section{Types of knowledge and types of scenarios}

Table 5 shows that when the principals were solving human relations scenarios, they used four subtypes of knowledge somewhat more often than others: tacit knowledge, knowledge of laws and regulations, knowledge of working with people, and knowledge of roles 
and responsibilities. In solving strategic problems, the principals referred much more frequently to knowledge of working with people and very little to knowledge of laws and regulations, strengths and weaknesses, and roles and responsibilities.

\section{Discussion}

\begin{tabular}{|l|c|c|}
\hline \multicolumn{3}{|l|}{$\begin{array}{l}\text { Table 5 - Relationship between Types of Knowledge and } \\
\text { Types of Challenges }\end{array}$} \\
\hline Types of knowledge & $\begin{array}{l}\text { Human } \\
\text { relations } \\
\text { scenarios }\end{array}$ & $\begin{array}{l}\text { Strategic } \\
\text { scenarios }\end{array}$ \\
\hline Tacit knowledge & $6 \%$ & $7 \%$ \\
\hline Constraints - external & 3 & 3 \\
\hline Constraints - internal & 2 & 6 \\
\hline Job complexity & 2 & 5 \\
\hline Laws and regulations & 9 & 1 \\
\hline Resources & 2 & 5 \\
\hline Time & 1 & 6 \\
\hline Competing interests & $<1$ & 6 \\
\hline Self & 2 & 2 \\
\hline Strengths and weaknesses & 2 & 1 \\
\hline Working with people & 9 & 15 \\
\hline Roles and responsibilities & 7 & 1 \\
\hline Total & $43 \% *$ & $57 \% *$ \\
\hline * Ignores discrepancies due to rounding up of the \\
percentages for specific types of knowledge.
\end{tabular}

The quality of principals' knowledge is related strongly to their effectiveness, particularly in problem solving and decision-making (Leithwood, Steinbach, and Raun, 1993). Moreover, research on the knowledge structures of leaders has indicated that they rely heavily on sophisticated problem representation: identifying key elements and patterns, characterizing problems in terms of fundamental principles rather than surface features (Chi, Feltovich, and Glaser, 1981; Frederiksen, 1990). My study has given a few highly effective principals a voice in the discourse to develop better understandings about such matters. And it has produced findings that address two of the issues identified at the beginning of this paper: (i) the matter of uncertainty about the kinds of knowledge that school principals now need, and (ii) the matter of rendering preparation programs more effective.

With regard to the knowledge issue, in the first place my findings align closely with those of Mumford,
Zaccaro, Harding, Jacobs, and Fleishman (2000). But they diverge in an interesting way from the findings of Sternberg and his colleagues. As noted earlier, Sternberg (1985) and Wagner and Sternberg (1985) found, as I did, that knowledge of people, tasks, and self is important for managerial success. But their fourth category of knowledge - how to build one's reputation - was not evident in the protocols of the principals who participated in my study. This difference may be tied to different orientations in the commercial and educational sectors to major values-including competitiveness.

Another contribution of my study is that it revealed 11 distinct subtypes within the three broad categories of knowledge used in tackling administrative challenges. In this connection, first of all, I found that the principals referred most often to organizational knowledge and its six subtypes, and among those subtypes two received the most attention: knowledge of laws and regulations, and knowledge of constraints both within and outside the school. This is in keeping with the consistent finding from studies of school improvement campaigns (like England's National Literacy and Numeracy Strategy) that effective school principals almost invariably tie their efforts very closely to bureaucratic prescriptions for "good" practice (e.g., Leithwood, Jantzi, Earl, Watson, Levin, and Fullan, 2004; Leithwood and Jantzi, 2006). One might speculate that this kind of knowledge pushes principals to seek solutions and make decisions that preserve the status quo. But it is interesting that the principals in my study paid more attention to constraints that existed within the school than those imposed from outside, such as school board and ministry decisions and policies. It is possible, of course, that this was a function of the specific problems with which they were presented. However, another possible explanation is suggested by the finding discussed next.

The next most frequently used general class of knowledge was knowledge of people, and within this the subtype "knowledge of working with people" received the most attention. This is consistent with evidence provided by others (e.g., Mumford and colleagues) that knowing how to manage people is a central element of leadership. In the principalship, this encompasses working with students, parents, administrator peers, communities, boards of education, and other stakeholders. It is also consistent with studies that show that effective principals accept that sometimes leadership must be provided by putative "followers", particularly when dealing with complex, ambiguous, and novel situations (Author, 
2006; Author, 2008; Leithwood, Mascall, Straus, Sacks, Memon, and Yashkina, 2007; MacBeath, 2005). Further, it is important to note that recent research and theorizing indicates that school principals must draw on multiple forms of leadership if they are to be successful in influencing or working with people to accomplish educational goals. More specifically, school principals must be informed about and skilled in providing a range of leadership styles that vary in the degree to which control is concentrated or dispersed - from the classic "heroic" mode through to the "quantum" or "dispersed" mode. This range of styles can be depicted as follows:

The "hero paradigm" of leadership emphasises the capabilities of one person to transform and improve an organ-

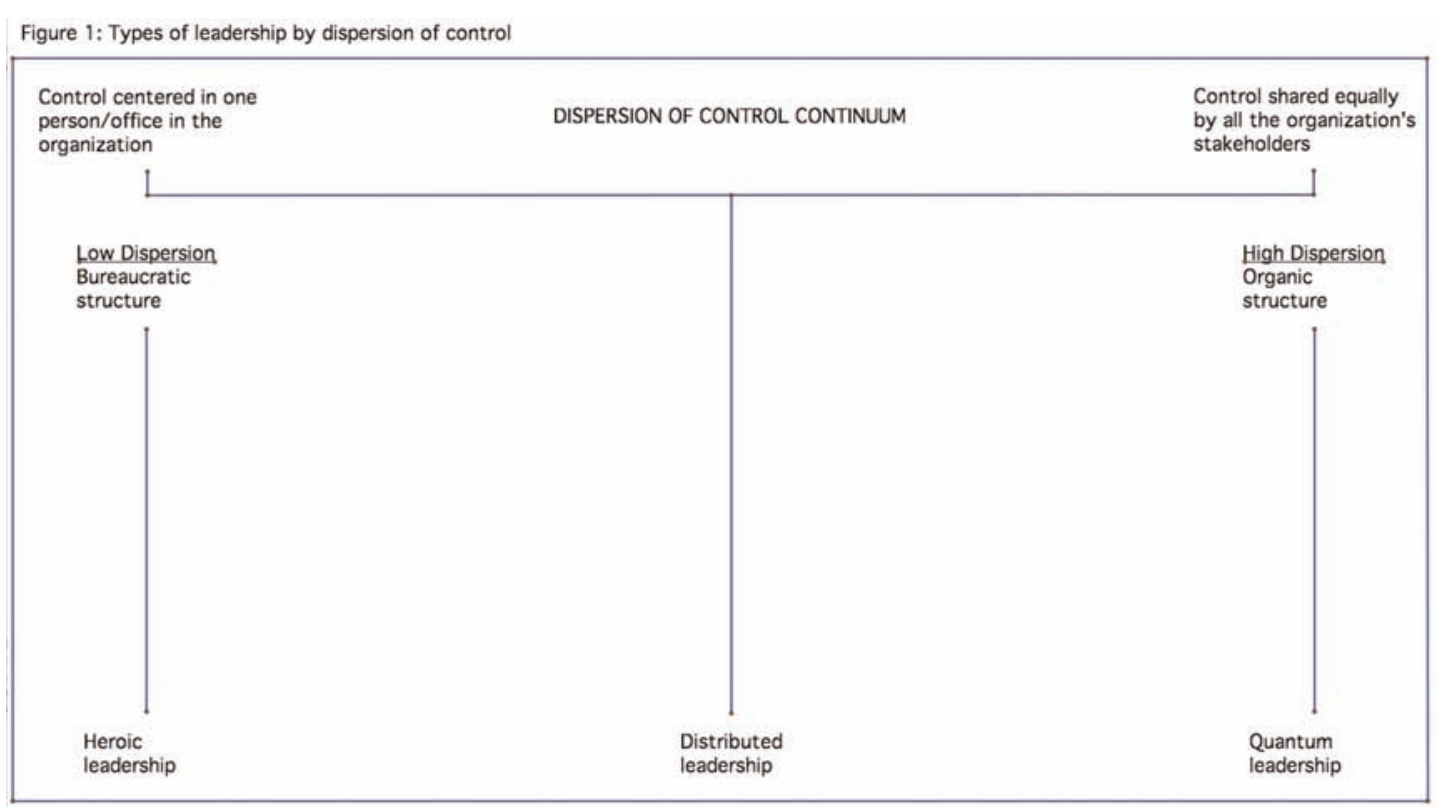
(Colleague and Author, 2006). working with people.

anywhere in the group contribute of their character, creativity, and abilities to advance the organization's mission. In this sense all the members of the collective are potential leaders rather than heroes, generals, orchestrators, or choreographers. The sources of leadership are individuals, networks, and, most important, interactions

Creating conditions in an organization that allow all forms of leadership would require esoteric knowledge of

The third category of knowledge that had been identified in previous research is knowledge of tasks. As noted earlier, one subtype within this general category was found to be salient: knowledge of roles and responsibilities, with the principals talking about the roles and responsibilities of teachers and teaching assistants, the role of students, and their role as educational leaders. Other researchers have reported similar findings about the importance of this type of knowledge (e.g., L e i t h w o o d, Steinbach, and Raun, 1993).

The fourth cat-

isation. The school leader is the locus of control, the gatekeeper of change.

Distributed leadership occurs when responsibility for leading work on various tasks is given over to individuals who have relevant expertise but who do not occupy formally designated leadership positions. However, it does not really entail a redistribution of power or control; rather, leadership responsibilities are allocated (and withdrawn) at the discretion of the formal leader:

I participate, we participate, but they decide what kinds of issues we can decide. (Wainwright, 2003, p. 193)

Quantum leadership typically occurs when the work to be done is rife with indeterminacy and ambiguity, and all members of the organization have equal opportunity to influence organizational activities — when individuals egory of knowledge that was evident in my data, tacit knowledge, contains the principals' representations or abstractions of past incidents. There were numerous instances of the principals drawing on examples from their experiences, both past and ongoing, to supported or justify proposed actions. This finding is congruent with other researchers' conclusion that abstract representations of situations influence how leaders define problems, evaluate restrictions, and implement plans (e.g., Sternberg and Wagner, 1993). The role of tacit knowledge in leaders' initiatives should be a focus for further studies, particularly because this would help cast more light on the role it plays in principals' expertise and effectiveness.

As reported earlier, it seems that the types of knowledge used varied with the type of issue. In the case of human relations challenges, the principals relied most heavily on their knowledge of laws and regulations, 
working with people, and roles and responsibilities. With strategic problems, though, they relied far more heavily on their knowledge of working with people than on other kinds of knowledge. In the absence of more data, these findings must remain tentative, but it seems that certain kinds of problems require specific kinds of knowledge. Further to the importance of knowing rules, regulations, and formal role specifications, one explanation may be that those prescriptions permit principals to negotiate with consistency not only bureaucratic prescriptions but also the complexities of human relations issues; after all, in the ideal, one important function of formal role expectations is to communicate and enforce basic principles of decency and fairness. This explanation is reinforced by the finding that the principals paid close attention to making sure that individuals understood fully (and in good time) what was expected of them in terms of the regulations that governed their jobs-which is a process that lawyers have established unequivocally as a core element of ensuring natural justice or fairness.

Another interesting finding was that knowledge of time and competing interests were of some significance in solving strategic problems but of negligible significance in resolving human relations issues. The explanation may lie in the fact that strategic problems emphasize effective and efficient task accomplishment. Managing time is an important component in the effective and efficient operation of a task-oriented situation; and dealing with individuals' competing interests ensures the sustained viability of the organization as a whole.

\section{Conclusion and Implications}

Historically, leadership theories have focused primarily on how leaders exercise interpersonal influence behaviourally. This line of research has a long pedigree, beginning with the seminal studies of Fleishman (1953) on consideration and initiating structure and continuing even into recent theories about distributed leadership. Addition of the cognitive approach does not discount the value of behavioural studies; rather, it extends them by identifying internal mechanisms that are needed to engage in leadership behaviours. The findings of my study extend understandings of principals' cognitive processes.

The cognitive approach to understanding principals' behaviours, moreover, is congruent with the need to test emerging conceptions that suggest leadership may emanate from the interactions through which the mem- bers of an organization co-create the personal and shared realities that influence their behaviours and thus the course of both small and large events in the organization (Author, 2008, pp. 10-14). Whenever this kind of leadership is called for, the nominal leader must know how the members of an organization co-create their realities and the knowledge they use so that an appropriate organizational culture can be nurtured. Accordingly, knowledge of people and how to work with them is indispensible (see Table 4, page 5).

Findings from cognitive inquiry recommend inclusion of a strong cognitive component in leaders' preparation programs. Cognitive psychologists have determined that expert leaders develop their expertise by (a) acquiring declarative knowledge, (b) compiling that knowledge into schemata (abstract structures built on connections between elements of knowledge), and (c) associating behavior routines with those schemata. The requisite knowledge is better learned in systematic professional development that includes instruction, modeling, practice, and feedback. The findings of this study provide useful guidance for the design of leaders' professional development, both personal and institutional, that builds on these principles. In this way my findings contribute to resolution of the knowledge issue outlined in the introduction to this paper.

At the same time, though, we must keep in mind that school principals are often under pressure to be "conservators and regulators of an existing order of affairs" (Zaleznik, 1992, p. 79). There is good evidence of this; for example:

- The principals who participated in my study drew heavily on their knowledge of their organizations, particularly knowledge of prescriptive laws, regulations, and formal role expectations (Table 4, above).

- Recent large-scale, international investigations of effective school principals (e.g., Day, 2005; Leithwood et al., 2007) have revealed that they tend to be good at implementing externally mandated curricula and student achievement standards (Author, 2008, pp. 9-10).

Therefore, to equip principals for their conservator/regulator role, preparation programs must also include components for the development of related skills.

On the other hand, there is a commensurate need to develop principals' knowledge of the need to challenge the status quo, so that they may become better equipped to respond to the criticism that schools support social 
reproduction that perpetuates inequities (e.g., Labaree, 1997; Dupriez and Dumai, 2006; ). Development of this knowledge, and the related skills, would be in keeping with such exhortations as, for example, the Interstate School Leaders Licensure Council's Standard 6:

A school administrator is an educational leader who promotes the success of all students by understanding, responding to, and influencing the larger political, social, economic, legal, and cultural context.

In the final analysis, it seems that principal preparation programs must incorporate both skills and cognitive training. One important area for improvement in preparation programs is the attention given to the development of experiential or tacit knowledge: the secondorder kind of knowledge that marks true expertise and governs how other kinds of knowledge and related skills are used. Field experiences or "practica" for trainees, together with opportunities for guided reflection with expert mentors, may have to be used more.

\section{References}

Allison, D., and Allison, P. (1993). Both ends of a telescope: Experience and expertise in principal problem-solving. Educational Administration Quarterly, 29(3), 302-322.

Anfara, V. A., and Valentine, J. (2004). Middle-level principal preparation and licensure. Retrieved at http://www.rmle.pdx.edu/Policy\%20Brief_Principal s.pdf

Archer, J. (2005). Leadership training seen to fall short. Education Week, 24(38), 9.

Association of Washington School Principals. (2006). Assessing and developing the 21st century principal. Lympia, WA; Author. Retrieved at http://www.awsp.org/Content/awsp/ProfessionalDev elopment/PrincipalAssessmentMentoring/default.ht $\mathrm{m}$

Athanasoula-Reppa, A., Lazaridou, A., and Lyman, L. (2006). Newly appointed principals in Greece and Cyprus: Perceptions of requirements, roles, and challenges. Paper presented at the Annual Conference of the Commonwealth Council for Educational Administration, October, Nicosia, Cyprus.

Australian Principals' Association Professional Development Council. (2002). Leaders lead succession planning: Building leadership capacity. Hindmarsh, South Australia: Australian Principals' Association Professional Development Council Inc.
Bainbridge, L. (1990). Verbal protocol analysis. In J. R. Wilson and E. N. Corlett (Eds.), Evaluation of human work: A practical ergonomics methodology. pp. 161-199. London, UK: Taylor and Francis.

Bottoms, G., and O'Neill, K. (2001). Preparing new school principals: It's time for action. Atlanta, GA: Southern Regional Education Board.

Brooking, K. (2007). Summary of the New Zealand literature on recruitment and retention of school leaders: Issues, challenges, trends, and strategies for succession planning. Wellington, NZ: New Zealand Council for Educational Research.

Creighton, T. B., and Jones, G. D. (2001). Selection or self-selection? How rigorous are our selection criteria for education administration preparation programs? Paper presented at the annual conference of the National Council of Professors of Educational Administration, Houston, Texas, August 7-11.

Cushman, K. (1992). Principals as coaches. Horace, 9(1). Retrieved at http://www.essentialschools.org/cs/resources/view/ce s_res/102

Daresh, J. (2002). U.S. school administrator development: Issues and a plan for improvement. In Lin Wen-liuh (Ed.), Proceedings of International Conference on School Leader Preparation, Licensure/Certification, Selection, Evaluation, and Professional Development. Taipei, Taiwan: National Taipei Teachers College.

Day, C. (2005). Principals who sustain success: Making a difference in challenging circumstances.

International Journal of Leadership in Education, 8(4), 273-290.

Dupriez, V., and Dumai, X. (2006). Inequalities in school systems: Effect of school structure or of society structure? Comparative Education, 42(2), pp. 243-260.

Educational Testing Services. (2005). School leaders licensure assessment. Retrieved at http://www.ets.org/Media/Tests/SLS/pdf/1010.pdf

Elmore, R. F. (2000). Building a new structure for school leadership. Washington, DC: The Albert Shanker Institute. Retrieved at http://www.shankerinstitute.org/Downloads/building.pdf

Ericsson, K. A., and Charness, N. (1994). Expert performance: Its structure and acquisition. American Psychologist, 49, 725-747. 
Ericsson, K. A., and Simon, H. A. (1993). Protocol analysis: Verbal reports as data. Cambridge, MA: MIT Press.

Eshleman, J. (2008). Skill. Retrieved at http://members.aol.com/johneshleman/glossary.html

Farkas, S., Johnson, J., and Duffett, A. (2003). Rolling up their sleeves: Superintendents and principals talk about what's needed to fix public schools. New York: Public Agenda.

Farkas, S., Johnson, J., Duffett, A., Foleno, T., and Foley, P. (2001). Trying to stay ahead of the game: Superintendents and principals talk about school leadership. Washington, DC: Public Agenda.

Fenwick, L. T. (2000). The principal shortage: Who will lead? Cambridge, MA: Harvard Graduate School of Education.

Ferrandino, V. L. (2001, February). Challenges for 21st century elementary school principals. Phi Delta Kappan, 82(6), 440-442.

Fleishman, E. A. (1953). Leadership climate, human relations training, and supervisory behavior. Personnel Psychology, 6, 205-222.

Chi, M. T. H., Feltovich, P. J., and Glaser, R. (1981). Categorization and representation of physics problems by experts and novices. Cognitive Science, 5, 121-152.

Colleague and Author. (2006). An additional way of thinking about organizational life and leadership: The quantum perspective. Canadian Journal of Educational Administration and Policy, 48.

Fullan, M. (2001). Leading in a culture of change. San Francisco, CA: Jossey-Bass.

Hess, F. M., and Kelly, A.P. (2006). Learning to lead: What gets taught in principal-preparation programs. Washington, DC: American Enterprise Institute. Retrieved at http://www.ksg.harvard.edu/pepg/PDF/Papers/Hess _Kelly_Learning_to_Lead_PEPG05.02.pdf (subscription required).

Hodgen, E., and Wylie, C. (2005). Stress and wellbeing among New Zealand principals. - Report to the New Zealand Principals' Federation. Wellington, NZ: New Zealand Council for Educational Research. Interstate School Leaders Licensure Consortium. (1996). Standards for school leaders. Retrieved 28 October 2008, at www.educ.ksu.edu/EDADL928/ISLLCstandards.pdf
Jones, J. C. (2000). Principal succession: A case study. Master's thesis, Department of Educational Research, University of Calgary.

Kail, R. V., and Bisanz, J. (1982). Cognitive strategies. In R. V. Kail and J. Bisanz (Eds.), Handbook of research methods in human memory and cognition. Hillsdale: NJ, Lawrence Erlbaum Associates.

KM-Experts. (2008). Skill. Retrieved at kmexperts.com/defs.htm

Labaree, D. (1997). Public goods, private goods: The American struggle over educational goals. American Educational Research Journal, 34(1), 39-81.

Lashway, L. (2003). Transforming principal preparation. ERIC Digest 165, February. Retrieved at cepm.uoregon.edu/publications/digests/digest 165.html

Lazaridou, A. (2002). An exploratory study of leaders' thinking in problem solving through protocol analysis. Doctoral dissertation, University of Alberta, Edmonton, Alberta, Canada.

Lazaridou, A. (2006). How effective principals think while solving problems. International Electronic Journal for Learning in Leadership, 10(15).

Lazaridou, A. and Fris, J. (2008). Slipping the yoke of the heroic paradigm: Looking for quantum leadership. Paper presented at the Annual Conference of the International Congress for School Effectiveness and Improvement, Auckland, New Zealand, 6-9 January.

Leithwood, K., and Jantzi, D. (1989). Expertise in principals' problem solving. Educational Administration Quarterly, 25, 121-161.

Leithwood, K., and Jantzi, D. (2006). Transformational school leadership for large-scale reform: Effects on students, teachers, and their classroom practices. School Effectiveness and School Improvement, 17(2), 201-227.

Leithwood, K., Jantzi, D., Earl, L., Watson, N., Levin, B., and Fullan, M. (2004). Strategic leadership for large-scale reform: The case of England's Numeracy and Literacy Strategy. School Leadership and Management, 24(1), 57-79.

Leithwood, K., Mascall, B., Strauss, T., Sacks, R., Memon, N., and Yashkina, A. (2007). Distributing leadership to make schools smarter: Taking the ego out of the system. Leadership and Policy in Schools, 6(1), 37-67.

Leithwood, K., and Steinbach, R. (1995). Expert problem solving: Evidence from school and district leaders. Albany, NY: State University of New York Press. 
Leithwood, K., Steinbach, R., and Raun, T. (1993). Superintendents' group problem-solving processes. Educational Administration Quarterly, 29(3), 364391.

Levine, A. (2005). Change in the principal's office: The role of universities. Chronicle of Higher Education, 51(32), B16.

Lumsden, L. S. (1992). Prospects in principal preparation. Eric Digest, 77.

Lyman, L. L., Ashby, D. E., and Tripses, J. S. (2005). Leaders who dare: Pushing the boundaries. Lanham, MD: Rowman and Littlefield Education.

Lyman, L. L., Athanasoula-Reppa, A., and Lazaridou, A. (2007). Greek and US women leaders' reflections about change and leadership. Paper presented at the Annual Conference of the Commonwealth Council for Educational Administration, October, Nicosia, Cyprus.

MacBeath, J. (2005). Leadership as distributed: A matter of practice. School Leadership and Management, 25(4), 349-366.

McIntyre, F. (1999). Leadership crunch hits Ontario. Professionally Speaking, June.

Mumford, M. D., Zaccaro, S. J., Harding,F. D., Jacobs, T. O., and Fleischman, E. A. (2000). Leadership skills for a changing world: Solving complex social problems. Leadership Quarterly, 11(1), 12-35.

Munby, S. (2006). School leadership: A national perspective. Nottingham, UK: National College for School Leadership.

National College for School Leadership. (2006). Leadership succession planning. Nottingham, UK: Author. Retrieved at http://www.ncsl.org.uk/media/8E2/2A/leadershipsuccession-birmingham-an-overview.pdf

Nestor-Baker, N. S., and Hoy, W. K. (2001). Tacit knowledge of school superintendents: Its nature, meaning, and content. Educational Administration Quarterly, 3(1), 86-129.

Normore, A. H. (2004). Recruitment and selection: Meeting the leadership shortage in one large Canadian school district. Canadian Journal of Educational Administration and Policy, I30, May 12.

Phillips, S. (2003). The Canadian principal. Education Analyst, Spring. Retrieved at http://www.saee.ca/analyst/C_018.2_BBB_LON.php

Prentice Hall. (2008). Skill. Retrieved at wps.prenhall.com/wps/media/objects/213/218150/g lossary.html
Pressley, M., and Afflerbach, P. (1995). Verbal protocols of reading: The nature of constructively responsive reading. Hillsdale: NJ: Erlbaum.

Price, J. M. C. (2002). The Neoliberal OZ: The Ontario College of Teachers' guidelines for the preparation of principals for the literacy and numeracy maquiladoras of Ontario. Retrieved at http://scholar.google.com/scholar?q=The+Neoliberal $+\mathrm{OZ} \% 3 \mathrm{~A}+\mathrm{The}+$ Ontario+College+of+Teachers\%E2\% 80\%99+guidelines+for+the+preparation+of+principals+for+the+literacy+and+numeracy+maquiladoras+of+Ontario. $\&$ hl=en $\& l \mathrm{r}=\& b \operatorname{tnG}=$ Search

Quinn, T. (2002). Succession planning: Start today. Retrieved from: www.nassp.org

Rascoe, P. (2007). An analysis of Virginia's high school principals' educational background, knowledge, and perceptions related to special education. Doctoral dissertation, Virginia Polytechnic Institute and State University, Blacksburg, Virginia.

Renihan, P. (n.d.). The Saskatchewan principalship study report four: Formula for effectiveness. Regina, SK: SSTA Research Centre.

Richardson, S. W. (1997). Principals for the schools of Texas: A seamless web of professional development. Fort Worth, TX: Sid W. Richardson Foundation.

Sergiovanni, T. J. (1996). Moral leadership: Getting to the heart of school improvement. San Francisco, CA: Jossey-Bass.

Smith, B.S., and Dawson, C.M. (1999). Applying the constructivist framework to principal preparation programs. Yearbook of the Southern Regional Council of School Administrators, 1(1). Retrieved at: http://www.hehd.clemson.edu/SRCEA/YrBkvlnl/S MITH.htm

Southworth, G. (2004). Primary school leadership in context: Leading small, medium, and large sized schools. London, UK: Routledge Falmer.

Sternberg, R. J. (1985). Beyond IQ: A triarchic theory of human intelligence. New York: Cambridge University Press.

Sternberg, R. J., and Wagner, R. K. (1993). The g-ocentric view of intelligence and job performance is wrong. Current Directions in Psychological Science, 2, $1-5$.

Taylor, K. L., and Dionne, J. P. (2000). Assessing problem-solving strategy knowledge: The complementary use of concurrent verbal protocols and retrospective debriefing. Journal of Educational Psychology, 92(3), 413-425. 
Temkin, J. (2004). Principal preparation panned. Catalyst Chicago, June 24.

Thomson, M. A., and Legler, R. (2003). The principalship and principal preparation. NCREL (North Central Region Education Laboratory) Policy Issues, Issue 14. Retrieved at http://www.ncrel.org/policy/pubs/html/pivoll4/aug2 003c.htm

U.S. Department of Labor. (2006). Occupational Outlook Handbook, 2006-07 Edition, Education Administrators. Washington, DC: Bureau of Labor Statistics. Retrieved at http://www.bls.gov/oco/ocos007.htm

Valentine, J. W., Clark, D. C., Hackman, D. G., and Petzko, V. N. (2002). A national study of leadership in middle level schools, Volume 1: A national study of middle level leaders and school programs. Reston, VA: National Association of Secondary School Principals.

Van Someren, M. W., Barnard, Y. F., and Sandberg, J. A. (1994). The think-aloud method: A practical guide to modeling cognitive processes. London: Academic Press.
Wagner, R. K. (1987). Tacit knowledge in everyday intelligent behavior. Journal of Personality and Social Psychology, 52(6), 1236-1247.

Wagner, R. K., and Sternberg, R. J. (1985). Practical intelligence in real-world pursuits: The role of tacit knowledge. Journal of Personality and Social Psychology, 49(2), 436-458.

Wagner, R. K., and Sternberg, R. J. (1986). Tacit knowledge and intelligence in the everyday world. In R. J. Sternberg and R. K. Wagner (Eds.), Practical intelligence (pp. 51-83). New York: Cambridge University Press.

Wikipedia. (2009). Skill. Retrieved at http://en.wikipedia.org/wiki/Skill_(disambiguation)

Zaleznik, A. (1992). Managers and leaders: Are they different? Harvard Business Review on Leadership, 1, 61-89.

IJEPL is a joint publication of the Association for Supervision and Curriculum Development, the Faculty of Education at Simon Fraser University, and the College of Education and Human Development at George Mason University. By virtue of their appearance in this open access journal, articles are free to use, with proper attribution, in educational and other non-commercial settings 90 days after initial publication. Copyright for articles published in IJEPL is retained by the authors. More information is available on the IJEPL Web site: http://www.ijepl.org 